\title{
Toxicological evaluation of an aqueous suspension from leaves and stems of Petiveria alliacea L. (Phytolaccaceae)
}

\author{
Martha-Estrella García-Pérez ${ }^{\mathrm{a}, \mathrm{c}}$, Alfredo Alfonso-Castillo ${ }^{\mathrm{b}}$, Onel Fong Lores ${ }^{\mathrm{b}}$, \\ Alexander Batista-Duharte ${ }^{\mathrm{b}, \mathrm{d}}$, Zoe Lemus-Rodríguez ${ }^{\mathrm{a}, *}$ \\ a Laboratorio Farmacéutico Oriente, Santiago de Cuba, Cuba \\ b Centro de Toxicología y Biomedicina (TOXIMED), Instituto Superior de Ciencias Médicas, Santiago de Cuba, Cuba \\ c Facultad de Químico-Farmacobiología, Universidad Michoacana de San Nicolás de Hidalgo, Morelia, Michoacán, México \\ ' São Paulo State University (UNESP), School of Pharmaceutical Sciences, Department of Clinica Analysis, Araraquara, SP, Brazil
}

\section{A R T I C L E I N F O}

\section{Keywords:}

Petiveria alliacea

Stems

Leaves

Acute toxic class method

Repeated dose toxicity

\begin{abstract}
A B S T R A C T
Ethnopharmacological relevance: Petiveria alliacea L. (Phytolaccaceae) is used in folk medicine due to its antispasmodic, diuretic, hypoglycemic, abortive, anti-inflammatory and anticancerogenic properties. Although $P$. alliacea is considered toxic by people, its toxicity remains a concern since it is strongly dependent on the extraction method and the part of the plant used during tests. Even if some healers prefer to use the aerial parts in a liquefied form or by chewing them, instead of decoctions or infusions, no toxicological studies exist using whole dried stems and leaves.

Materials and methods: The toxicity of a suspension of the powder from the leaves and stems of $P$. alliacea was assessed in Sprague Dawley rats by oral administration using two tests: 1) the acute toxic class method, which allows classification of substances according to their intrinsic toxicity and 2) the repeated dose 28-day method, following the guidelines 423 and 407 respectively from the Organization for the Economic Cooperation and Development. Chemical characterization of this powder was performed by GC-MS, UV-fluorescence, proximate and elemental analysis.

Results and conclusions: $P$. alliacea powder from stems and leaves was classed in the hazard category 5 $\left(\mathrm{LD}_{50}>2000 \mathrm{mg} / \mathrm{kg}\right)$ according to the acute toxicology study. There were no toxicity signs at $1000 \mathrm{mg} / \mathrm{kg}$ in the repeated dose study, although higher values of total leukocytes were found in the satellite and males of the experimental group, which were attributed to the immunomodulatory properties of this plant. According to GCMS, the prevailing compounds identified were phytol, (R)-(-)-(Z)-14-methyl-8-hexadecen-1-ol, 1-(2-hydrohyethyl)-1,2,4-triazole and methyl $\beta$-dimethylaminoisobutyrate. In conclusion, the oral administration of the $P$. alliacea powder to Sprague Dawley rats did not result in deaths and was not associated with adverse effects reflected in the general condition, body weights or histopathological abnormalities.
\end{abstract}

\section{Introduction}

Petiveria alliacea L. (Phytolaccaceae) is a perennial shrub indigenous to the Amazon Rainforest which grows in the Caribbean, also known as "Anamú". In Cuban folk medicine, it is used by its antispasmodic, diuretic, hypoglycemiant, and anticancerogenic properties (Roig, 1974)

One of the most important properties of Anamú, referred by Cuban herbalists, is the capacity to modulate the immunological system (Illnait Ferrer, 2007; Lemus-Rodríquez et al., 2004). Some in vitro and in vivo studies support this claim. $P$. alliacea increases the number of granulocyte-macrophage progenitors in the bone marrow and up-regulates the antibacterial immune response by enhancing the Th1 lymphocyte function and the natural killer activity of mice infected with Listeria monocytogenes (Quadros et al., 1999; Queiroz et al., 2000). Moreover, Batista-Duharte et al. (2011) reported a protective effect of a suspension of the powder, made from leaves and stems of this plant, on the immunosuppression induced by 5 -fluoruracil in mice (Batista Duharte et al., 2011).

Though it is not clear what molecules are responsible for its immunomodulatory properties, it has been suggested that dibenzyl trisulphide (DTS), a lipophilic (non-polar) compound present in the leaves and stems of this plant, could be implied in this activity (Rösner et al., 2001; Williams et al., 1997). DTS increases the weight of murine thymus and also protects mice exposed to a lethal dose of E.coli

\footnotetext{
* Corresponding author.

E-mail address: zoe.lemus@infomed.sld.cu (Z. Lemus-Rodríguez).
} 
(Delaveau et al., 1980; Williams et al., 1997). This compound, which was identified among other non-polar molecules in the ethyl acetate fraction collected from leaves and stems of $P$. alliacea, has also shown a cytotoxic activity over several tumor cell lines (Urueña et al., 2008). However, the immunomodulatory activity of $P$. alliacea seems to be also mediated by metabolites of polar nature. Santander et al. (2012) found that the aqueous fraction from the residue of the ethanol-insoluble extract of stems and leaves of Anamú induces dendritic cell activation by increasing NF-KB gene expression, thus suggesting that hydrophilic (polar) metabolites such as sugars and phenolic compounds could also be involved in the immunomodulatory activity of this plant. Interestingly, these effects were not observed for the organic fraction, which is mainly composed of lipophilic compounds such as leridal/petiveral, 7demethyl leridal and DTS (Santander et al., 2012). These studies suggest that both, polar and non-polar metabolites from leaves and stems, act by different mechanisms, thereby contributing to the immunomodulatory properties of this species. This fact could explain why some healers prefer to use the aerial parts of this plant by liquefying or chewing them, instead of decoctions or infusions. By this way, molecules with different polarities and activities are obtained, treating different diseases such as cancer, whereas in the decoctions or infusions polar compounds are mainly extracted (Martínez-Pilar et al., 2003; Navarro, 2008).

Although the immune modulation can protect the host from cancer, the unappropriated immunological overactivation leads to destructive and sometimes life-threatening diseases. Therefore, special care must be taken regarding toxicity of immunomodulatory agents to ensure their safety (Batista-Duharte et al., 2011; Haley, 2012).

Even though $P$. alliacea is considered a toxic plant for people (Oliveira et al., 2015), results of toxicological tests using different extracts from this plant are controversial (Luz et al., 2016). Indeed, it seems that the sample preparation, tissue used during extraction, the extraction method and the route of administration may have an impact on the toxicological outcomes (Blainski et al., 2010; Bussmann et al., 2011; Kim et al., 2006). Season and region of collection can also influence the toxicity of this plant (Luz et al., 2016). Significant alterations in the bronchioles, trachea and lungs were observed in female Wistar rats exposed to the steams of $P$. alliacea root $(150 \mathrm{~g})$ during 3 min (Fletes-Arjona et al., 2013). However, the hydroalcoholic extract of $P$. alliacea roots by intraperitoneal administration shows low acute toxicity at $100-400 \mathrm{mg} / \mathrm{kg}$ in female Swiss mice (Gomes, 2006). The ethanoic extract of $P$. alliacea aerial parts $(300 \mathrm{mg} / \mathrm{kg})$ can induce anxiogenic effects in mice, whereas no effects are observed with root extract (Blainski et al., 2010). The ethanolic extract of $P$. alliacea whole plant also shows more toxicity $\left(\mathrm{LC}_{50}=0.67 \mu \mathrm{g} \mathrm{mL}^{-1}\right.$ ) than the aqueous one $\left(\mathrm{LC}_{50}=126 \mu \mathrm{g} \mathrm{mL}^{-1}\right.$ ) on a brine-shrimp assay (Bussmann et al., 2011). The aforementioned discrepancies in toxicological outcomes can be a consequence of significant changes in relative concentrations of toxic compounds present in $P$. alliacea depending on sample preparation. Indeed, Kim et al. (2006) demonstrated that freshly prepared plant macerates of this species presents a different organosulfur compound profile than those from dried plant or heat-treated extracts (Kim et al., 2006).

To date, toxicological assessments using leaves and stems of this plant have used ethanolic, aqueous or hydroalcoholic extracts in which mainly polar compounds are present. However, no studies were found regarding the toxicity of non-extracted leaves and stems. Unlike extracts, powders from whole plant tissues have a higher chemical complexity as they contain a greater number of metabolites, which can negatively or positively impact on toxicity. No toxicity signs were observed after the administration of hydroalcoholic extract (up to $3000 \mathrm{mg} / \mathrm{kg}$ ) from aerial parts of P.alliacea (Audi et al., 2001). However, the aqueous extract of P.alliacea leaves at $1000 \mathrm{mg} / \mathrm{kg}$ caused an increase in blood glucose and a decrease of hematocrit in mice, although no deaths were reported (García-González et al., 2006). These results suggest that more extensive studies are required using $P$. alliacea to improve the knowledge about its toxicity considering different plant preparations representative of its use in traditional medicine.

Taking into account the extensive use of leaves and stems of Anamú by Cuban healers and the fact that toxicological evaluations have been made with its alcoholic, hydroalcoholic or aqueous extracts showing diverse results; in this study, we aimed to evaluate the acute and subacute toxicity of an aqueous suspension using a powder from Anamú's leaves and stems, simulating another form of administration of this plant by the folk medicine.

\section{Materials and methods}

\subsection{Botanical analysis}

Stems and leaves of $P$. alliacea were from the estate named "La Rosita", from Santiago de Cuba, Cuba. It is a certified farm that has provided medicinal plants to the pharmaceutical industry with the highest standards of phytosanitary quality (collection for toxicological studies: 05/2001, chemical characterization: 05/2017).

Leaves and stems were identified by Florentino Bermúdez, botanist of the "Centro Oriental para Ecosistemas y Biodiversidad" in Santiago de Cuba, and deposited in this herbarium (voucher number: 4997). Before used, the plant material was washed and oven dried (temperature $<35{ }^{\circ} \mathrm{C} ; 5-6 \%$ humidity), it was then grounded at a particle size of $\leq 125 \mu \mathrm{m}$.

\subsection{Phytochemical profile of $P$. alliacea}

\subsubsection{Fractionation}

The fractionation procedure followed the method described by Santander et al. (2012), with some modifications (Santander et al., 2012). P. alliacea leaves and stems as dry powder ( $15 \mathrm{~g}$ ) was firstly extracted using a Soxhlet $\left(60{ }^{\circ} \mathrm{C}\right)$ with $96 \%$ ethanol $(300 \mathrm{~mL})$ for $3 \mathrm{~h}$ and solids were separated by filtration with a Whatman No. 4 filter paper and washed with $300 \mathrm{~mL}$ of ethanol. The extract (PAE) was concentrated under vacuum $\left(35^{\circ} \mathrm{C}, 29 \mathrm{kPa}\right)$. PAE was then resuspended in $300 \mathrm{~mL}$ water, decanted through a $100-\mathrm{mL}$ Gooch crucible (Pyrex ${ }^{\circ}$, $40-60 \mu \mathrm{m}$, coarse porosity) and the filtrate collected in a $500 \mathrm{~mL}$ Erlenmeyer flask. In a separation funnel, the aqueous solution was first extracted with hexane $(3 \times 100 \mathrm{~mL}$, Phase A) and then with ethyl acetate $(3 \times 100 \mathrm{~mL}$, Phase $\mathrm{B})$. The aqueous solution was called Phase C. The three phases were evaporated under vacuum to remove hexane $\left(40{ }^{\circ} \mathrm{C}, 23 \mathrm{kPa}\right)$, ethyl acetate $\left(60{ }^{\circ} \mathrm{C}, 21 \mathrm{kPa}\right)$ and water $\left(60{ }^{\circ} \mathrm{C}, 29 \mathrm{kPa}\right)$, resuspended in ethanol $1 \%(\mathrm{w} / \mathrm{w})$ and filtered through a $50-\mathrm{mL}$ Gooch crucible (Pyrex ${ }^{\circ}, 40-60 \mu \mathrm{m}$, coarse porosity). The solutions were kept under refrigeration $\left(4^{\circ} \mathrm{C}\right)$ until the analysis.

\subsubsection{Gas chromatography-mass spectrometry (GC-MS)}

The phases A, B and C were analyzed by GC-MS using an Agilent Technologies 7890 A GC set up (Agilent 19091S-433 HP-5MS column: $325^{\circ} \mathrm{C}: 30 \mathrm{~m} \times 250 \mu \mathrm{m} \times 0.25 \mu \mathrm{m}$, Agilent $5975 \mathrm{C}$ MS with NIST $2.0 \mathrm{f}$ Mass Spectral Search Program). This technique has been used for identification of volatiles compounds characteristic of this plant (Neves et al., 2011; Santander et al., 2012; Sathiyabalan et al., 2014). Small samples $(1.8 \mathrm{~mL})$ were collected with a filter unit for syringe (Miller ${ }^{\circ}$ GP Filter Unit $0.22 \mu \mathrm{m}$ ) from the stock solutions for the GC-MS analysis. The GC/MS analytical method used is as follows: front inlet $\left(250{ }^{\circ} \mathrm{C}\right.$, total flow He $24 \mathrm{~mL} / \mathrm{min}$, septum purge flow $3 \mathrm{~mL} / \mathrm{min}$; Split ratio $30: 1,30 \mathrm{~mL} / \mathrm{min})$, column flow $(1 \mathrm{~mL} / \mathrm{min})$, oven $\left(40{ }^{\circ} \mathrm{C}\right.$ for $3 \mathrm{~min}$, ramp to 280 at $3{ }^{\circ} \mathrm{C} / \mathrm{min}$ ). The end of the column was directly introduced into the ion source of the mass selective detector operated with electron impact ionization mode. The data acquisition system used was G1034C Chemstation software with a NBS library (2008).

\subsubsection{Proximate analysis}

Fixed carbon, volatiles, and ash content for phases A, B and C were 
determined with a thermogravimetric analyzer (TGA), SDTA851e (Mettler Toledo, US). Briefly, five to $8 \mathrm{mg}$ of each sample was heated from room temperature to $378 \mathrm{~K}$ at a rate of $10 \mathrm{~K} \mathrm{~min}^{-1}$ and held at $378 \mathrm{~K}$ for $15 \mathrm{~min}$. Next, the samples were heated from 378 to $873 \mathrm{~K}$ at $30 \mathrm{~K} \mathrm{~min}^{-1}$ and held for $10 \mathrm{~min}$. The thermogravimetric method was performed under nitrogen atmosphere $\left(100 \mathrm{~cm}^{3} \mathrm{~min}^{-1}\right)$. The gas was then changed to oxygen and the sample was left to combust. The remaining mass was reported as ash. The percentage of fixed carbon was determined by subtracting ash percentage from volatile matter percentage, after assigning all weight loss up to $423 \mathrm{~K}$ to loss of free and non-structural water.

\subsubsection{Elemental analysis}

Elemental analysis $(\mathrm{C}, \mathrm{H}, \mathrm{N})$ on all samples $(0.1 \mathrm{~g}$ plus addition of $0.3 \mathrm{~g}$ of Leco's Com-Aid) were determined using a Leco TruSpec CHN 628 series instrument according to ASTM D5373-08 (2008). The sulfur analysis was determined by the combustion method using a Leco $628 \mathrm{~S}$ series. The oxygen content was calculated by difference.

\subsubsection{UV-fluorescence}

Fluorescence analysis has been used as pharmacognostic procedure useful in the identification of herbal drugs, as it provides an idea about the chemical nature of the constituents present in plants or a particular extract (Alam and Us Saqib, 2015). Phases A, B and C were diluted in HPLC grade methanol at $10 \mathrm{ppm}$ and analyzed on Shimadzu RF $5301 \mathrm{pc}$ spectrometer (software: Panorama Fluorescence 2.1). Synchronous fluorescence spectra at constant wavelength difference were set up. Excitation wavelength was scanned from 250 to $500 \mathrm{~nm}$, and emission wavelengths were recorded with a $5 \mathrm{~nm}$ difference (from 260 to $510 \mathrm{~nm}$ ). The excitation slit width and emission slit width were set up at $5 \mathrm{~nm}$. Data was collected every $1 \mathrm{~nm}$.

\subsection{Animals}

Experimentation with animals was accomplished according to the International Principles of Good Laboratory Practice (OECD, 1999) and the Principles of Care and Use of Laboratory Animals (Institute for Laboratory Animal Research, 2011). Sprague Dawley rats of both sexes, 6-8 weeks age, were obtained from CENPALAB (Havana, Cuba). The experimental design was reviewed and approved by the Institutional Ethics Committee for Animal Use in Research and the Department of Quality Guarantee, Toxicology and Biomedicine Center, Santiago de Cuba. (Protocol TOXIMED/UGC/010404). Animals were of both sexes, with 150-200 g weight. Females were nulliparous and non-pregnant. Animals were housed in a conventional environment. Before the tests, animals were randomly acclimated (one per cage) for 7 days with a schedule of $12 \mathrm{~h}$ light: $12 \mathrm{~h}$ dark. The room of the animals was maintained at $22 \pm 3{ }^{\circ} \mathrm{C}$ with $65 \%$ relative humidity. Water and Certified Rodent Diet were provided ad libitum (Formula EMO:1002) (ALYco, CENPALAB, Havana, Cuba) in granulated form. Feed and water were sterilized by autoclaving at $120^{\circ} \mathrm{C}$ for $60 \mathrm{~min}$ for water and during $20 \mathrm{~min}$ for feed.

\subsection{Toxicity of the plant in rodents}

Toxicity of the $P$. alliacea powder was assessed using two tests: 1) the acute toxic class method which allows to classify substances according to their intrinsic toxicity and 2) the repeated dose 28-day subacute method which examines adverse events other than death for a longer period. Both studies were performed following guidelines 423 (with minor modifications) and 407 respectively, from the Organization for the Economic Cooperation and Development (OECD) (OECD, 2008, 2002). For these tests, Anamú powder ( $3 \mathrm{~g}$ ) was freshly prepared in $30 \mathrm{~mL}$ aqueous suspension containing carboxymethyl cellulose (CMC) $(0.5 \% \mathrm{w} / \mathrm{v})$ simulating its traditional use and administered to Sprague Dawley rats by gavage.

\subsubsection{Acute toxic class method}

Sprague Dawley rats were divided into 2 groups of 3 animals (3 males and 3 females). The Anamú suspension was administered at $2000 \mathrm{mg} / \mathrm{Kg}$ body weight by gavage, beginning with females followed by males $48 \mathrm{~h}$ later. After the drug administration, animals were observed until day 14 to determine death or the presence of toxicity signs and symptoms (morphological, physiological, and behavioral changes). Pre-and post-treatment body weights were measured at the days 0,7 and 14 at the same hour for treated groups. All animals were subjected to necropsy after 14 days and anesthetized with ketamine hydrochloride at $50 \mathrm{mg} / \mathrm{Kg}$ b.w. The vital organs (lung, heart, liver, spleen, intestine and kidney) were prepared in paraffin, stained with hematoxylin-eosin and observed under an optical microscope (Culling, 2013).

\subsubsection{Repeated dose 28-day oral toxicity study}

As no effects were expected at a dose of $1000 \mathrm{mg} / \mathrm{Kg}$ bw/d, a limit test was performed to analyze the repeated exposure in rats during 28 days (OECD, 2008). Before the experiment, Sprague Dawley rats were allowed to acclimatize for 7 days. Then, they were randomly divided into 3 groups of 10 animals ( 5 males and 5 females) and the $P$. alliacea suspension or vehicle (aqueous CMC suspension $0,5 \% \mathrm{w} / \mathrm{v}$ ) was administered daily as follows: a) Control group ( $50 \mathrm{mg} / \mathrm{Kg} \mathrm{bw} / \mathrm{d}$ vehicle); b) Experimental group (1000 mg/Kg bw/d Anamú suspension); c) Satellite group $(1000 \mathrm{mg} / \mathrm{Kg} \mathrm{bw} / \mathrm{d}$ Anamú suspension). The satellite group (SG) was used to verify the reversibility, persistence or delayed occurrence of toxic effects (OECD, 2008). Body weights were measured at the days $0,7,14,21$ and 28 at the same hour. After administration, animals were observed twice daily in order to determine death or the presence of toxicity sign and symptoms. After 28 and 42 days, animals were subjected to necropsy and anesthetized with ketamine hydrochloride $(50 \mathrm{mg} / \mathrm{Kg}$ bw). Main organs including liver, spleen, kidney, heart, and thymus were collected and weighted. Relative organ weight was calculated based on the following: Relative organ weight (\%) = organ weight/body weight $\times 100$ (Zhang et al., 2017).

Blood was withdrawn from the aorta for assessment of hematology and clinical chemistry. Organs and tissues such as brain, spinal cord, lymph nodes, heart, adrenals, intestine, uterus, urinary bladder, stomach, thyroid gland, testis/ovaries, thymus, liver, kidneys and spleen were excised and fixed in $10 \%$ buffered formalin and prepared in paraffin according to the conventional method. The preparations were stained with hematoxylin-eosin and observed under an optical microscope (Culling, 2013).

2.4.2.1. Hematological determinations. The following hematological examinations were made: hemoglobin concentration (HGB, Hemotest D0912-30, ENCOMED, La Habana, Cuba), total (TLC) and differential leukocyte count (TDC), hematocrit (HCT) and platelet count (PLC). The HGB was determined using the Drabkin method (Drabkin, 1949). The TLC and PLC were performed with a Neubauer chamber via optical microscopy (Colina et al., 1989). TDC was determined from a blood smear stained with May-Gruwald- Giemsa (R-6-0492-E, ENCOMED, La Habana, Cuba) (Montanher et al., 2007). HCT as percentage was determined with a microhematocrit centrifuge by measuring the percent of packed red cell height, regarding to the total height (Colina et al., 1989).

2.4.2.2. Biochemical determinations. The following plasma biochemical parameters were determined: serum glutamic pyruvic transaminase (SGPT, D0301-03, ENCOMED, La Habana, Cuba), serum glutamic oxaloacetic transaminase (SGOT, D0301-04, ENCOMED, La Habana, Cuba), glucose (GLC, D95-0720, ENCOMED, La Habana, Cuba), urea (UR), total serum proteins (TSP), total cholesterol (TC, D0204-05, ENCOMED, La Habana, Cuba). SGPT and SGOT were determined by the colorimetric method described by Reitman and Frankel (1957). GLC was determined via colorimetric reaction using a Glucose Oxidase 
Reagent (Rapid Gluco Test, Elfa Diagnostics ${ }^{\circledast}$ ) and measured at $530 \mathrm{~nm}$. The UR concentration was determined using the Berthelot method (Bishop et al., 2013) whereas the concentration of TSP was examined by the Biuret method (Ziestchem Diagnostics Kit, Tehran, Iran). TC in the serum was analyzed by the Pearson method (Pearson et al., 1953).

\subsection{Statistical analysis}

Experimental results were expressed as means \pm SD. Results were analyzed by a Kruskal-Wallis analysis of variance (ANOVA) to compare the body weight at different times $(* \mathrm{p}<0.05)$. Differences between sexes for a particular time were compared using a Mann-Whitney test. Means were separated by Nemenyi's post hoc test using SAS program 8.2 software (SAS Institute Inc., Cary, NC, USA). Organ weights were compared using Student's unpaired $t$-test $\left({ }^{*} \mathrm{p}<0.05\right)$. Hematologic and biochemical parameters were analyzed by an analysis of variance (ANOVA) and means were separated by a Duncan test (*p $<0.05$ ).

\section{Results and discussion}

Animals treated with $P$. alliacea at $2000 \mathrm{mg} / \mathrm{kg}$ in the acute toxic class method, showed neither mortality nor any toxicity signs during 14 days. Females and males significantly increased their body weight at days 0,7 and 14 (*p $<0.05$ ) (Fig. 1). No significant lesions or pathological changes attributable to $P$. alliacea treatment were found in the organs of animals in the treated or control group (data not shown). $P$. alliacea powder was classified in the hazard category 5 according to the Globally Harmonized System (OECD, 2002). These results are in accord with other investigations which did not find any toxicity signs with orally administered aqueous extract of $P$. alliacea leaves or the whole plant extract at $2000 \mathrm{mg} / \mathrm{kg}$ (de Andrade et al., 2012; García-González

A) A cute toxic class method

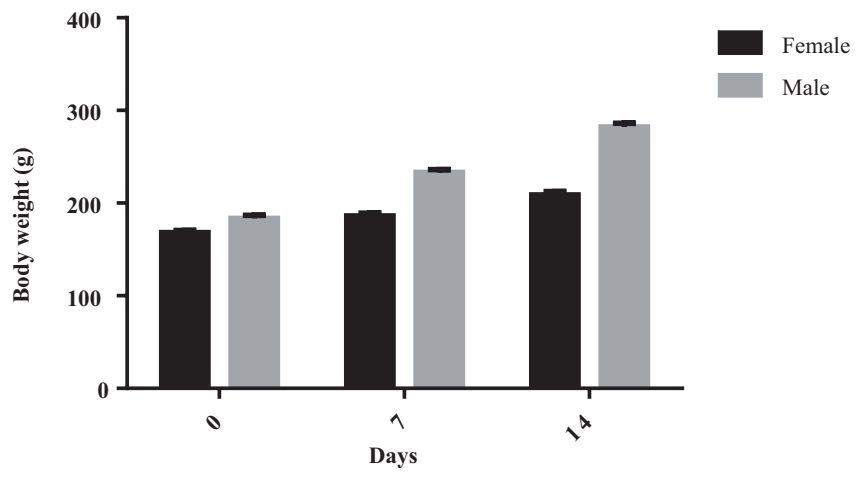

et al., 2006).

In the repeated dose study, there were neither treatment-related toxicity signs nor mortality at $1000 \mathrm{mg} / \mathrm{kg}$ for 28 and 42 days. Indeed, a gain of weight was observed in all groups at days 7, 14, 21 and 28 (*p $<0.05$ ) (Fig. 1). The repeated oral administration of the aqueous suspension of $P$. alliacea leaves and stems did not affect the macroscopic characteristics of organs related to their appearance and color. In this study, histopathological evaluation, and microscopic examination of organs from treated and control groups showed a normal structure without significant detrimental changes or morphological disturbances caused by daily oral administration of the $P$. alliacea suspension (data not shown).

Hematological analysis is shown in Table 1. The hematocrit significantly decreased in females of SG whereas platelet count decreased in the experimental and satellite groups compared to the control (*p $<0.05)$. Although statistically significant, the hematocrit diminution was mild and within biological variability of this specie (Probst et al., 2006). Indeed, lower hematocrit levels in females compared with males have been reported (Probst et al., 2006). Platelet count decrease in experimental and SG, although significant, fall within normal values reported in rodents (Harkness et al., 2010). However, the fact that only treated groups had this diminution, leads to think that it could be a potential adverse effect related to this plant. Although $P$. alliacea has shown platelet antiaggregant activity (Villar et al., 1997), no reports were found about its thrombocytopenic properties. Further, deeper specific studies are necessary to clarify this effect.

Leukocytes and lymphocytes increased in males of the experimental group and in the SG, whereas neutrophils were solely significantly increased in SG (Table 1$)(* \mathrm{p}<0.05)$. The immunomodulatory properties of this plant could explain these effects. Indeed, it has been previously demonstrated that a $P$. alliacea suspension from stems and leaves at

Fig. 1. Effect of the $P$. alliacea leaves and stem's oral administration on the body weight of Sprague Dowley rats by the acute toxic class method and by the 28-day oral toxicity study. Values represent means $\pm \mathrm{SEM}$.

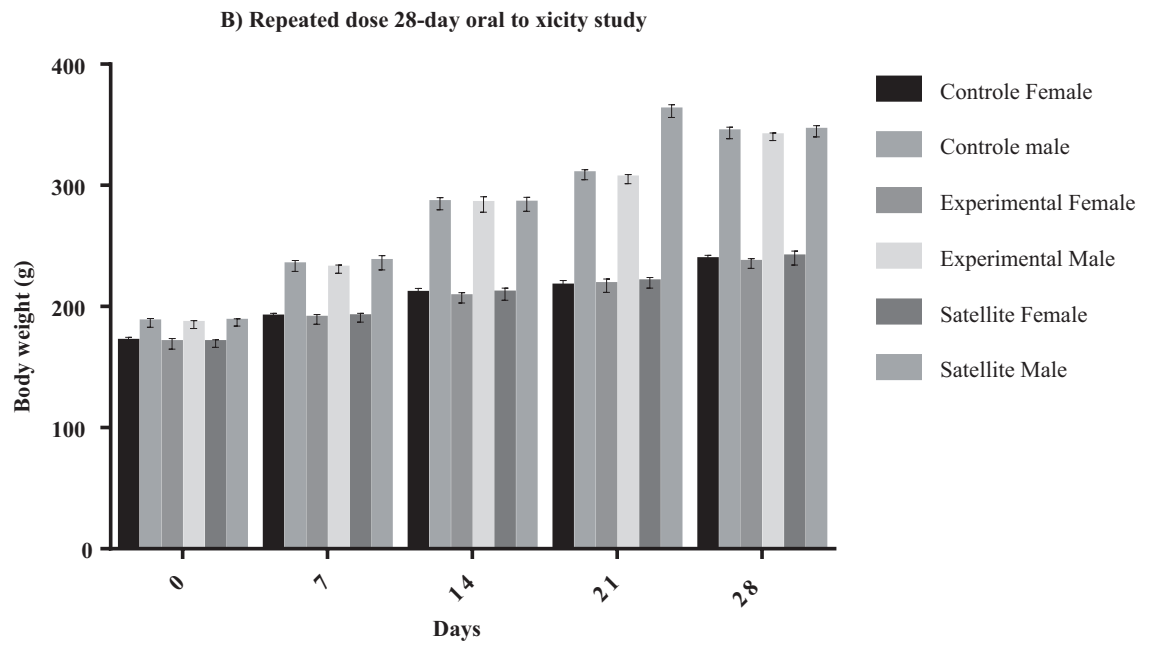


Table 1

Effect of $P$. alliacea oral administration on hematological parameters in Sprague Dawley rats.

\begin{tabular}{|c|c|c|c|c|c|c|c|}
\hline Groups & Sex & Hemoglobin $\left(\mathrm{g} \mathrm{L}^{-1}\right)$ & Hematocrit (\%) & Platelet $\left(\times 10^{3} \mathrm{~mm}^{3}\right)$ & Leukocytes $\left(\times 10^{9} \mathrm{~L}^{-1}\right)$ & Neutrophils $\left(\times 10^{9} \mathrm{~L}^{-1}\right)$ & Lymphocytes $\left(\times 10^{9} \mathrm{~L}^{-1}\right)$ \\
\hline \multirow[t]{2}{*}{ C } & $\mathrm{F}$ & $136.4 \pm 2.70^{\mathrm{a}}$ & $44.20 \pm 1.64^{\mathrm{a}}$ & $356.20 \pm 10.64^{\mathrm{a}}$ & $5.26 \pm 0.46^{\mathrm{a}}$ & $0.19 \pm 0.08^{\mathrm{a}}$ & $5.03 \pm 0.56^{\mathrm{a}}$ \\
\hline & M & $137.2 \pm 0.84^{\mathrm{a}}$ & $46.40 \pm 1.14^{\mathrm{b}}$ & $351.60 \pm 4.98^{\mathrm{a}}$ & $5.46 \pm 0.54^{\mathrm{a}}$ & $0.29 \pm 0.14^{\mathrm{a}}$ & $5.17 \pm 0.59^{\mathrm{a}}$ \\
\hline \multirow[t]{2}{*}{$\mathrm{E}$} & $\mathrm{F}$ & $136.4 \pm 1.14^{\mathrm{a}}$ & $44.00 \pm 0.71^{\mathrm{a}}$ & $323.60 \pm 27.28^{\mathrm{b}}$ & $6.30 \pm 0.58^{\mathrm{ab}}$ & $0.18 \pm 0.19^{\mathrm{a}}$ & $5.90 \pm 0.60^{\mathrm{a}}$ \\
\hline & M & $137.4 \pm 0.55^{\mathrm{a}}$ & $46.20 \pm 0.84^{\mathrm{b}}$ & $321.00 \pm 9.62^{b}$ & $6.66 \pm 0.82^{\mathrm{b}}$ & $0.21 \pm 0.12^{\mathrm{a}}$ & $6.80 \pm 1.24^{\mathrm{b}}$ \\
\hline \multirow[t]{2}{*}{ S } & $\mathrm{F}$ & $137.00 \pm 1.00^{\mathrm{a}}$ & $42.40 \pm 1.14^{\mathrm{c}}$ & $325.20 \pm 18.78^{\mathrm{bc}}$ & $6.80 \pm 1.41^{\mathrm{b}}$ & $0.45 \pm 0.23^{\mathrm{b}}$ & $6.44 \pm 1.13^{\mathrm{b}}$ \\
\hline & M & $138.0 \pm 0.71^{\mathrm{a}}$ & $46.20 \pm 0.45^{\mathrm{b}}$ & $323.40 \pm 15.34^{\mathrm{b}}$ & $7.32 \pm 1.25^{\mathrm{b}}$ & $0.52 \pm 0.12^{\mathrm{b}}$ & $6.91 \pm 1.38^{\mathrm{b}}$ \\
\hline
\end{tabular}

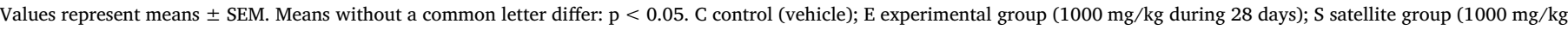
during 42 days); F females; $M$ males.

Table 2

Relative weights of thymus, spleen, heart, liver and kidney of Sprague Dawley rats subchronically treated with a suspension of P.alliacea leaves and stems.

\begin{tabular}{llllll}
\hline \multirow{2}{*}{ Organs } & \multicolumn{2}{l}{ Males relative organ weight (\%) } & & Females relative organ weight (\%) \\
\cline { 2 - 3 } \cline { 5 - 6 } \cline { 5 - 6 } & Control Group & $\begin{array}{c}\text { P.alliacea } \\
(\mathbf{1 0 0 0} \mathbf{~} \mathbf{m g} / \mathbf{k g})\end{array}$ & & Control Group & $\begin{array}{l}\text { P.alliacea } \\
(\mathbf{1 0 0 0} \mathbf{~ m g} / \mathbf{k g})\end{array}$ \\
\hline Thymus & $0.12 \pm 0.01$ & $0.11 \pm 0.01$ & & $0.14 \pm 0.01$ & $0.14 \pm 0.01$ \\
Spleen & $0.21 \pm 0.01$ & $0.25 \pm 0.02$ & & $0.22 \pm 0.02$ & $0.24 \pm 0.02$ \\
Heart & $0.39 \pm 0.03$ & $0.39 \pm 0.03$ & & $0.37 \pm 0.05$ & $0.35 \pm 0.02$ \\
Liver & $2.67 \pm 0.22$ & $2.83 \pm 0.20$ & & $2.51 \pm 0.18$ & $2.67 \pm 0.21$ \\
Kidney & $0.81 \pm 0.04$ & $0.84 \pm 0.10$ & & $0.72 \pm 0.04$ & $0.71 \pm 0.04$ \\
\hline
\end{tabular}

Values represent means \pm SEM.

${ }^{*} \mathrm{p}<0.05$ against control group.

$1200 \mathrm{mg} / \mathrm{kg}$ increases the total leukocyte and neutrophil count in Balb/ c mice (Batista Duharte et al., 2011). Moreover, P. alliacea has demonstrated to increase the phagocytotic index of the mice granulocytes (Williams et al., 1997). Additionally, it can induce lymphocytosis, together with an increase of bone marrow cellularity (Batista Duharte et al., 2011).

Table 2 shows the organ weights of the treated and control groups. An increase in spleen-to-body weight ratio for males of the experimental group ( $p=0.0174$ ) was observed (Table 2). These results differed from those reported by Batista-Duharte et al. (2011), who found that administration of a suspension of stems and leaves from $P$. alliacea $(1200 \mathrm{mg} / \mathrm{kg}$ ) together with 5-fluorouracil in mice did not increase the spleen weight, although it significantly increased the number of lymphocytes and neutrophils in peripheral blood (Batista Duharte et al., 2011). The change in spleen weight here observed could be attributed to the immunomodulatory properties of this plant. However, the spleen weight change was solely observed for males and did not correlate with histopathologic findings, as no morphological disturbances in this organ were observed (data not shown). It has been reported that spleen weight changes do not always correlate with histopathologic findings. Indeed, spleen weight can change due to interanimal variability, stressrelated effects, and physiologic factors unrelated to treatment such as euthanasia-associated splenic congestion (Michael et al., 2007). Given the immunomodulatory properties reported for P. alliacea (Batista Duharte et al., 2011; Williams et al., 1997), other studies considering greater exposure times to the plant should be performed to confirm its effects on organs of immunological importance such as the spleen.

Biochemical analysis of the subacute study is shown in Table 3. No significant differences were observed regarding glucose levels between experimental groups. This result is inconsistent to previous investigations which showed an increase in fasting and blood glucose after oral administration of aqueous extracts from $P$. alliacea leaves in rodents at 400 and $1000 \mathrm{mg} \mathrm{kg}^{-1}$ respectively (Christie and Levy, 2013; GarcíaGonzález et al., 2006).

An increase in SGPT in males of the experimental group and in SG was observed, whereas SGOT significantly increased in the SG ( $\left.{ }^{*} \mathrm{p}<0.05\right)$. A higher transaminase level has been reported after $10 \mathrm{~g} /$ $\mathrm{kg}$ Anamú ingestion in bovines (Núñez et al., 1983). Although these values fall within biological variability of Sprague Dawley rats, the increase in transaminases in the SG regarding to the control and experimental groups could be a delayed toxic effect related to a higher exposition of Anamú. Moreover, the diminution in total serum protein in the experimental and SG could indicate a hepatic overload due to the plant administration. More studies should be performed to determine the toxicity of Anamú stems and leaves for more than 28 days to evaluate if it can cause delayed hepatic toxicity.

According to GC-MS analysis, sixteen, twenty-six and twenty-two compounds were identified in phases A (yield $=5.4 \%$ on dry $P$.alliacea powder wt.), B (yield $=4.3 \%$ ) and C (yield $=2.0 \%$ ) from $P$. alliacea stems and leaves (Fig. 2 and Table 4). The prevailing compounds in these fractions were determined to be phytol, (R)-(-)-(Z)-14-methyl-8hexadecen-1-ol, 1-(2-hydrohyethyl)-1,2,4-triazole and methyl $\beta$-dimethylaminoisobutyrate. It is also interesting to note the occurrence of the S-benzyl phenylmethanethiosulfonate (compound 12, phase A) in stems and leaves of this specie. The presence of a related compound, Sbenzyl phenylmethanethiosulfinate, has been documented in a $P$. alliacea root homogenate (Kubec et al., 2002).

The important presence of phytol has been also described in $P$. alliacea tissues (Aderoju et al., 2017; Kerdudo et al., 2015; Sathiyabalan et al., 2014). Phytol is an acyclic monounsaturated diterpene alcohol, present in vitamins $\mathrm{K}$ and $\mathrm{E}$. Phytol derivatives are considered as excellent immunostimulants in terms of long-term memory induction and activation of innate and acquired immunity (Chowdhury and Ghosh, 2012). Considering its significant occurrence in stems and leaves of this plant, it is possible that this compound be related to the increase of leukocytes and lymphocytes in males of the experimental group and in the SG. However, further studies using this isolated molecule should be performed to confirm such effects.

Results of proximate and elemental analysis are shown in Table 5. Value of total ash found for the $P$. alliacea powder was similar to that recently reported (13.50 vs. $12.04 \%)$ for stems and leaves of the plant, indicating a low content of inorganic contaminants (García-Pérez et al., 2017). Volatile compounds were higher in phase C, while phase B showed the most important content of fixed carbon. As for the elemental analysis, phase B (ethyl acetate) demonstrated to have an important content of carbon, hydrogen and sulfur, whereas phase $\mathrm{C}$ (aqueous) contained a large amount of sulfur, oxygen and nitrogen. If we suppose that a mixture of pure protein contains $16 \%$ of nitrogen, it is possible to estimate the content of proteins in the samples multiplying the content of $\mathrm{N}$ by a factor of 6.25 (Mariotti et al., 2008). Using this conversion factor, we can estimate the protein content in the original plant of $25.6 \mathrm{wt} \%$. The content of proteins in phase A, B and C was 9.4, 12.5 and $58.7 \mathrm{wt} \%$. respectively. This result confirms that Phase $\mathrm{C}$ extracted with water is very rich in proteins. Another investigation also confirmed the significant proteins occurrence in the aqueous fraction $(927 \mathrm{~g} / \mathrm{mL})$ obtained from the residue ethanol-insoluble of P.alliacea dry ground leaves and stems (Santander et al., 2012). Interestingly, this fraction, unlike the organic fraction (ethyl acetate soluble fraction), is able to influence the cellular microenvironment of dendritic cells (Santander et al., 2012) showing immunomodulatory activity.

Polyphenols are among the most important compounds described in 
Table 3

Effect of $P$. alliacea oral administration on the serum chemistry in Sprague Dawley rats.

\begin{tabular}{|c|c|c|c|c|c|c|c|c|}
\hline Groups & Sex & SGPT $\left(\mathrm{U} \mathrm{L}^{-1}\right)$ & SGOT $\left(\mathrm{U} \mathrm{L}^{-1}\right)$ & GLC $\left(\mathrm{mmol} \mathrm{L}^{-1}\right)$ & $\mathrm{UR}\left(\mathrm{mmol} \mathrm{L} \mathrm{L}^{-1}\right)$ & $\operatorname{TSP}\left(\mathrm{g} \mathrm{L}^{-1}\right)$ & $\operatorname{ALB}\left(\mathrm{g} \mathrm{L}^{-1}\right)$ & $\mathrm{TC}\left(\mathrm{mmol} \mathrm{L}^{-1}\right)$ \\
\hline \multirow[t]{2}{*}{$\mathrm{C}$} & $\mathrm{F}$ & $24.26 \pm 1.33^{\mathrm{a}}$ & $51.30 \pm 2.69^{\mathrm{a}}$ & $5.30 \pm 0.19^{\mathrm{a}}$ & $4.88 \pm 0.19^{\mathrm{a}}$ & $70.00 \pm 4.18^{\mathrm{a}}$ & $39.60 \pm 3.51^{\mathrm{a}}$ & $2.06 \pm 0.22^{\mathrm{a}}$ \\
\hline & M & $25.56 \pm 1.93^{\mathrm{a}}$ & $53.42 \pm 6.25^{\mathrm{a}}$ & $5.44 \pm 0.11^{\mathrm{a}}$ & $5.04 \pm 0.15^{\mathrm{a}}$ & $69.80 \pm 1.48^{\mathrm{a}}$ & $39.80 \pm 3.70^{\mathrm{a}}$ & $2.06 \pm 0.06^{\mathrm{a}}$ \\
\hline \multirow[t]{2}{*}{ E } & $\mathrm{F}$ & $24.96 \pm 3.17^{\mathrm{a}}$ & $54.14 \pm 3.09^{\mathrm{a}}$ & $5.32 \pm 0.22^{\mathrm{a}}$ & $4.76 \pm 0.21^{\mathrm{a}}$ & $65.40 \pm 1.67^{b}$ & $38.20 \pm 5.49^{\mathrm{a}}$ & $1.96 \pm 0.11^{\mathrm{a}}$ \\
\hline & M & $28.58 \pm 3.89^{b}$ & $54.52 \pm 2.09^{\mathrm{a}}$ & $5.48 \pm 0.15^{\mathrm{a}}$ & $5.14 \pm 0.47^{\mathrm{a}}$ & $65.20 \pm 0.84^{b}$ & $38.60 \pm 3.43^{\mathrm{a}}$ & $2.02 \pm 0.16^{\mathrm{a}}$ \\
\hline \multirow[t]{2}{*}{ S } & $\mathrm{F}$ & $28.38 \pm 3.12^{\mathrm{b}}$ & $59.80 \pm 0.99^{\mathrm{b}}$ & $5.24 \pm 0.15^{\mathrm{a}}$ & $5.08 \pm 0.11^{\mathrm{a}}$ & $64.20 \pm 1.79^{\mathrm{b}}$ & $35.20 \pm 2.58^{\mathrm{a}}$ & $1.88 \pm 0.19^{\mathrm{a}}$ \\
\hline & M & $30.30 \pm 1.70^{\mathrm{b}}$ & $61.60 \pm 1.67^{\mathrm{b}}$ & $5.36 \pm 0.15^{\mathrm{a}}$ & $5.12 \pm 0.22^{\mathrm{a}}$ & $64.20 \pm 0.84^{b}$ & $36.80 \pm 2.68^{\mathrm{a}}$ & $1.90 \pm 0.20^{\mathrm{a}}$ \\
\hline
\end{tabular}

Values represent means \pm SEM. Means without a common letter differ: $\mathrm{p}<0.05$.

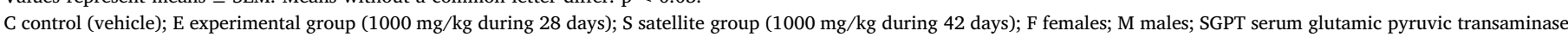
alanine transaminase; SGOT serum glutamic oxaloacetic transaminase aspartate transaminase; GLC glucose; UR urea; TSP total serum proteins; ALB albumin; TC total cholesterol.

P. alliacea. The mean value of phenolic content in a powder of $P$. alliacea leaves and stems was determined to be $0.33 \%$ (García-Pérez et al., 2017). These molecules are present as simple phenols, short conjugated systems and polycondensed structures (polymeric tannins). Different conformers with different dihedral angles between aromatic rings characterize phenol dimers, oligomers and polymeric structures.
Indeed, each conformer gives its own contribution to the absorption and fluorescence spectra (Barsotti et al., 2016). It was recently demonstrated that excitation wavelength increases as rings grow to clusters of four. Beyond four rings the increase in ring size does not affect excitation wavelength. This is mostly due to that the transitions causing fluorescence involve only three consecutive phenolic rings
Phase A
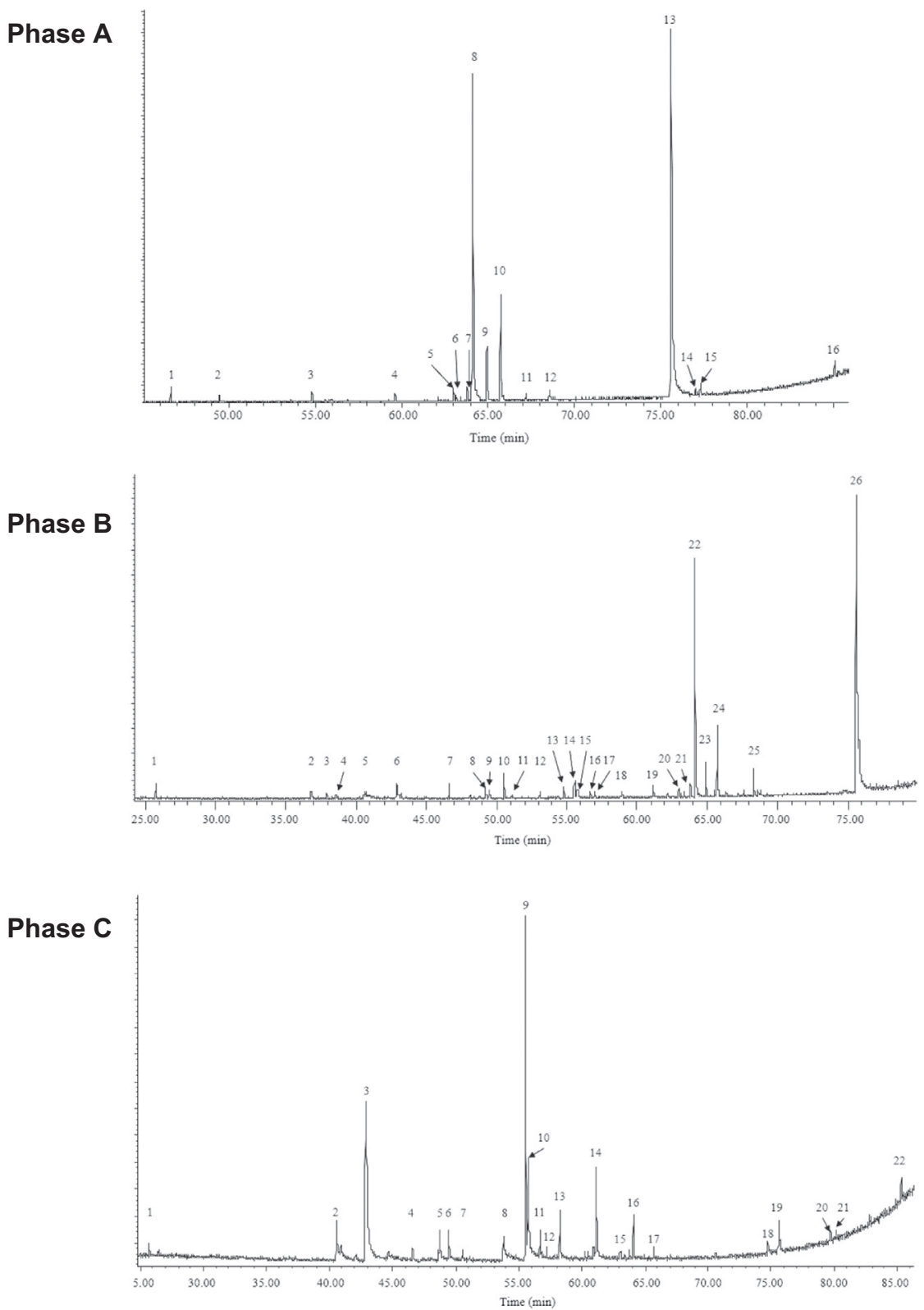

Fig. 2. Compound identified by GC-MS in stems and leaves of $P$. alliacea. Phase A (Hexane); B (ethyl acetate) and C (Aqueous fraction). 
Table 4

Compounds identified in Petiveria alliacea leaves and stems by GC-MS (RT: retention time, $\min )$.

\begin{tabular}{|c|c|c|}
\hline No. & RT & Phase A. Identified compounds \\
\hline 1 & 46.62 & E-11,13-Tetradecadien-1-ol \\
\hline 2 & 49.45 & Malonamic acid \\
\hline 3 & 54.80 & 3-n-Hexylthiolane, S,S-dioxide \\
\hline 4 & 59.64 & 1,2-Benzenediol. O-(acethoxyacetyl)-O'-(1-naphthoyl) \\
\hline 5 & 62.98 & Benzophenone \\
\hline 6 & 63.17 & 2,5-Dihydroxybenzoic acid \\
\hline 7 & 63.77 & 1R,2c,3t,4t-Tetramethyl-cyclohexaxe \\
\hline 8 & 64.11 & (R)-(-)-(Z) - 14-Methyl-8-hexadecen-1-ol \\
\hline 9 & 64.93 & 3,7,11,15-Tetramethyl-2-hexadecen-1-ol \\
\hline 10 & 65.71 & 3-Eicosyne \\
\hline 11 & 67.19 & 4-Metroxy-6-methyl-6,7-dihydro-4H-furo(3,2-c)pyran \\
\hline 12 & 68.59 & S-Benzyl phenylmethanethiosulfonate \\
\hline 13 & 75.61 & Phytol \\
\hline 14 & 77.30 & 1-Oxaspiro[2.5]octane, 4,4-dimethyl-8-methylene \\
\hline 15 & 77.40 & Benzonitrile, m-phenethyl- \\
\hline 16 & 85.08 & $\begin{array}{l}\text { 3-Benzyl-6-ethyl-4-oxo-3,4-dihydrothieno[2,3-d] pyrimidine- } \\
\text { 2-carboxylic acid, amide }\end{array}$ \\
\hline No. & RT (min) & Phase B. Identified compounds \\
\hline 1 & 25.73 & 2-Pentanone, 4-hydroxy-4-methyl- \\
\hline 2 & 36.78 & Belzyl phosphide \\
\hline 3 & 37.95 & 1,2-Ethanediol, 1,2-diphenyl-, $\left(\mathrm{R}^{*}, \mathrm{R}^{*}\right)-( \pm)$ - \\
\hline 4 & 38.55 & Pyrimidine, 5-methyl- \\
\hline 5 & 40.94 & 1,2,3,4-Butanetetrol, [S-( $\left.\left.\mathrm{R}^{*}, \mathrm{R}^{*}\right)\right]-$ \\
\hline 6 & 42.92 & I-4-Hycroxylysine lactone \\
\hline 7 & 46.62 & E-11,13-Tetradecadien-1-ol \\
\hline 8 & 49.20 & 1H-Pyrrole-2,5-dione, 3-ethyl-4-methy \\
\hline 9 & 49.45 & 1,2-Ethanediamine, N,N'-diethyl- \\
\hline 10 & 50.55 & Benzenamine, N-ethyl-3-methyl \\
\hline 11 & 51.06 & 4-Methyleneproline \\
\hline 12 & 53.10 & Benzene, 1-isocyano-2-methyl- \\
\hline 13 & 54.79 & 11-Tricosene \\
\hline 14 & 55.55 & Phenol, 4-[2-(dimethylamino)ethyl]- \\
\hline 15 & 55.76 & 1,4-Bis[3-(dimethylamino)propionyl]benzene \\
\hline 16 & 56.69 & S-Benzoyl(thiohydroxylamine) \\
\hline 17 & 57.00 & L-Glutamine \\
\hline 18 & 58.91 & Benzeneacetamide \\
\hline 19 & 61.14 & Indole \\
\hline 20 & 62.98 & 1,2.3-Butanetrione, 1-phenyl-,2,3-dioxime \\
\hline 21 & 63.78 & 1R,2c,3t,4t-Tetramethyl-cyclohexaxe \\
\hline 22 & 64.11 & (R)-(-)-(Z)-14-Methyl-8-hexadecen-1-ol \\
\hline 23 & 64.92 & 3,7,11,15-Tetramethyl-2-hexadecen-1-ol \\
\hline 24 & 65.71 & 3-Eicosyne \\
\hline 25 & 68.35 & 2-Fluorobenzoic acid, 2-formyl-4,6-dichlorophenyl ester \\
\hline 26 & 75.61 & Phytol \\
\hline No. & RT (min) & Phase C. Identified compounds \\
\hline 1 & 25.70 & 2-Nonanone, 9-hydroxy \\
\hline 2 & 40.74 & 1,2,3,4-Butanetetrol, [S-(R*-R*)] \\
\hline 3 & 42.89 & 1-(2-Hydrohyethyl)-1,2,4-triazole \\
\hline 4 & 46.62 & Arginine \\
\hline 5 & 48.77 & 2-Propanone,1-(dimethylamino)- \\
\hline 6 & 49.47 & 4-(2-Dimethylaminoethoxy)benzonitrile \\
\hline 7 & 50.57 & Benzenamine, 2-methoxy-N,N-dimethyl- \\
\hline 8 & 53.82 & Imidazole-2-carboxylic acid, 4-methyl- \\
\hline 9 & 55.59 & Methyl $\beta$-dimethylaminoisobutyrate \\
\hline 10 & 55.79 & 2-butanone,4-(dimethylamino) - 3-methyl- \\
\hline 11 & 56.68 & S-Benzoyl(thiohydroxylamine) \\
\hline 12 & 57.23 & 1-Piperidinepropanoic acid \\
\hline 13 & 58.24 & L-Proline, 5-oxo-, methyl ester \\
\hline 14 & 61.14 & Cis-3-Hydroxy-2-propylpiperidine \\
\hline 15 & 63.78 & Pyrrolidine, 1,1'.methyllenebis- \\
\hline 16 & 64.10 & (R)-(-)-(Z)-14-Methyl-8-hexadecen-1-ol \\
\hline 17 & 65.70 & Ciclodecanol \\
\hline 18 & 74.76 & Apigerin 7-glucoside \\
\hline 19 & 75.59 & Phytol \\
\hline 20 & 79.71 & $\begin{array}{l}\text { Benzothiophene-3-carboxylic acid, 4,5,6,7-tetrahydro-2- } \\
\text { amino-6-ethyl-, ethyl ester }\end{array}$ \\
\hline 21 & 80.19 & 5-Iodohistidine \\
\hline 22 & 85.33 & Sicilic acid, diethyl bis(trimethysilyl) ester \\
\hline
\end{tabular}

Phase A (Hexane), B (Ethyl Acetate), C (Water).
Table 5

Proximate and elemental analysis of P.alliacea stems and leaves dry powder (on dry basis wt\%).

\begin{tabular}{llllll}
\hline Proximate analysis & & & & \\
\hline Sample & Volatiles & Fixed carbon & Ash \\
\hline P. alliacea stems and leaves dry powder & 79.6 & & 6.9 & \multicolumn{2}{l}{13.5} \\
Phase A (Hexane) & 93.8 & 5.8 & 0.4 & \\
Phase B (Ethyl Acetate) & 91.0 & 6.2 & 2.8 & \\
Phase C (Water) & 94.1 & & 0.01 & 5.8 & \\
Elemental analysis & & & & & \\
Sample & $C$ & $H$ & $N$ & & $O^{\text {a }}$ \\
P. alliacea stems and leaves dry powder & 40.0 & 5.6 & 4.1 & 0.2 & 36.6 \\
Phase A (Hexane) & 65.0 & 9.4 & 1.5 & 0.3 & 23.4 \\
Phase B (Ethyl Acetate) & 70.6 & 10.2 & 2.0 & 0.4 & 14.0 \\
Phase C (Water) & 36.0 & 6.4 & 9.4 & 0.4 & 42.0 \\
& & & & &
\end{tabular}

${ }^{\text {a }}$ By difference.

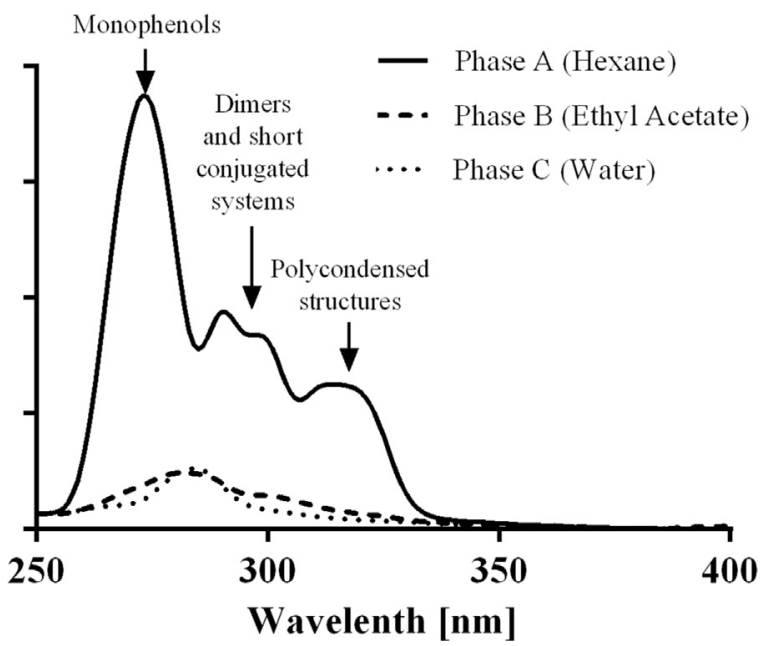

Fig. 3. UV Fluorescence spectra of different phases derived from $P$. alliacea stems and leaves.

(Barsotti et al., 2016).

Fig. 3 shows the UV fluorescence spectra of different phases obtained from P.alliacea stems and leaves. These results confirm that the hexane fraction is very rich in small and large conjugated structures likely to be associated with small mono-phenols, terpenes, furans and to large oligo phenols. Other exhaustive studies by HPLC and NMR are needed to elucidate the nature of the molecules present in hexane and other fractions, in order to identify the compounds involved in the immunomodulatory and toxic properties of $P$. alliacea.

\section{Conclusions}

P. alliacea powder was classed in the hazard category 5 $\left(\mathrm{LD}_{50}>2000 \mathrm{mg} / \mathrm{kg}\right.$ ) according to the acute toxicology study. There were no changes in animal's behavior at $1000 \mathrm{mg} / \mathrm{kg}$ in the subacute study. However, low platelet count and high values of total leukocytes were found in treating groups, as well as a transaminase increase in SG and a diminution in total serum protein indicating a probable hepatic overload due to plant administration. As it is the first toxicological assessment using whole dried stems and leaves powder in a suspension form, instead of extracts, discrepancies from previous studies support the criteria of other authors which sustain that the toxicology of this plant is strongly depend on extraction procedure and tissue used during the investigations.

Considering that the toxicity of $P$. alliacea may also vary depending on the region where the plant is collected, results here presented partially support the toxicological properties of the stems and leaves of this 
species. Further investigations should be accomplished to elucidate the mechanisms of toxicity related to the presence of specific compounds depending on the plant part, season, and region of collection.

\section{Conflict of interest}

The authors declare no conflict of interest.

\section{Acknowledgements}

Authors would like to thank the "Laboratorio Farmacéutico Oriente" for the financial support of this investigation (Grant number: F60011001).

\section{References}

Aderoju, A., Opeyemi, N., Omikorede, O., Ogunwande, I., Oladipupo, A., 2017. Study on the chemical constituents and anti-inflammatory activity of essential oil of Petiveria alliacea L. Br. J. Pharm. Res. 15, 1-8.

Alam, F., Us Saqib, Q.N., 2015. Pharmacognostic study and development of quality control parameters for fruit, bark and leaf of Zanthoxylum armatum (Rutaceae). Anc. Sci. Life 34, 147-155, http://dx doi.org/10.4103/0257-7941.157159.

de Andrade, T.M., de Melo, A.S., Dias, R.G.C., Varela, E.L.P., de Oliveira, F.R., Vieira, J.L.F., de Andrade, M.A., Baetas, A.C., Monteiro, M.C., Maia, C., do, S.F., 2012. Potential behavioral and pro-oxidant effects of Petiveria alliacea L. extract in adult rats. J. Ethnopharmacol. 143, 604-610. http://dx.doi.org/10.1016/j.jep.2012.07. 020 .

ASTM D5373-08, 2008. Standard Test Methods for Instrumental Determination of Carbon, Hydrogen, and Nitrogen in Laboratory Samples of Coal. ASTM International, West Conshohocken, PA.

Audi, E., De Campos, E.J., Rufino, M., Cortez, D., Bersani-Amado, C., Soarez, L.A., De Mello, J.C., 2001. Petiveria alliacea L.: plant drug quality control, hydroalcoholic extract standardization and pharmacological assay of lyophilized extract. Acta Farm. Bonaer. 20, 225-232.

Barsotti, F., Ghigo, G., Vione, D., 2016. Computational assessment of the fluorescence emission of phenol oligomers: a possible insight into the fluorescence properties of humic-like substances (HULIS). J. Photochem. Photobiol. Chem. 315, 87-93. http:// dx.doi.org/10.1016/j.jphotochem.2015.09.012.

Batista Duharte, A., Urdaneta Laffita, I., Colón Suárez, M., Esmérido Betancourt, J., Puente Zapata, E., Alfonso Castillo, A., Salas Martínez, H., Rodríguez, L., Zoe, M., 2011. Efecto protector de Petiveria alliacea L. (Anamú) sobre la inmunosupresión inducida por 5-fluoruracilo en ratones Balb/c. Bol. Latinoam. Caribe Plantas Med. Aromát. 10, 256-264.

Batista-Duharte, A., Lindblad, E.B., Oviedo-Orta, E., 2011. Progress in understanding adjuvant immunotoxicity mechanisms. Toxicol. Lett. 203, 97-105. http://dx.doi.org/ 10.1016/j.toxlet.2011.03.001.

Bishop, M., Fody, E., Schoeff, L., 2013. Clinical Chemistry: Principles, Techniques, and Correlations, 7 ed. Wolters Kluwer, PA, USA.

Blainski, A., Piccolo, V.K., Mello, J.C.P., de Oliveira, R.M.W., 2010. Dual effects of crude extracts obtained from Petiveria alliacea L. (Phytolaccaceae) on experimental anxiety in mice. J. Ethnopharmacol. 128, 541-544.

Bussmann, R.W., Malca, G., Glenn, A., Sharon, D., Nilsen, B., Parris, B., Dubose, D., Ruiz, D., Saleda, J., Martinez, M., Carillo, L., Walker, K., Kuhlman, A., Townesmith, A., 2011. Toxicity of medicinal plants used in traditional medicine in Northern Peru. J. Ethnopharmacol. 137, 121-140. http://dx.doi.org/10.1016/j.jep.2011.04.071.

Chowdhury, R.R., Ghosh, S.K., 2012. Phytol-derived novel isoprenoid immunostimulants. Front. Immunol. 3, 49. http://dx.doi.org/10.3389/fimmu.2012.00049.

Christie, S.-L., Levy, A., 2013. Evaluation of the hypoglycaemic activity of Petiveria alliacea (guinea Hen Weed) extracts in normoglycaemic and diabetic rat models. West Indian Med. J. 62, 685-691.

Colina, J., Alvarez R.E., Cruz C., Ballester J.S., Ballester A.S., 1989. Laboratorio. Ed. Pueblo y Educación, Ciudad de la Habana, Cuba.

Culling, C.F.A., 2013. Handbook of Histopathological and Histochemical Techniques: Including Museum Techniques, 3rd ed. Butterworth-Heinemann, Massachussets, USA.

Delaveau, P., Lallouette, P., Tessier, A.M., 1980. Drogues Végétales Stimulant l'Activité Phagocytaire du Système Réticuio-Endothélial1. Planta Med. 40, 49-54. http://dx. doi.org/10.1055/s-2008-1074941.

Drabkin, D.L., 1949. The standardization of hemoglobin measurement. Am. J. Med. Sci. 217,710 .

Fletes-Arjona, V.M., Soto-Domínguez, A., García-Garza, R., Morán-Martínez, J., BenítezValle, C., Castañeda-Martínez, A., Montalvo-González, R., Becerra-Verdín, E.M., 2013. Alteraciones Morfológicas en el Tracto Respiratorio de Ratas Wistar Inducidas por Vapores de la Raíz de Hierba del Zorrillo (Petiveria alliacea) del Suroeste de México. Int. J. Morphol. 31, 121-127. http://dx.doi.org/10.4067/S071795022013000100019.

García-González, M., Coto Morales, T., Ocampo, R., Pazos, L., 2006. Subchronic and acute preclinic toxicity and some pharmacological effects of the water extract from leaves of Petiveria alliacea (Phytolaccaceae. Rev. Biol. Trop. 54, 1323-1326.

García-Pérez, M.-E., Lemus-Rodríguez, Z., Hung-Arbelo, M., Vistel-Vigo, M., 2017. Influence of polyvinylpyrrolidone, microcrystalline cellulose and colloidal silicon dioxide on technological characteristics of a high-dose Petiveria alliacea tablet. Drug Dev. Ind. Pharm. 1-5. http://dx.doi.org/10.1080/03639045.2017.1359621.

Gomes, P., 2006. Avaliação dos efeitos centrais e antinociceptivos das frações isoladas das raízes de Petiveria alliacea L. (Tipi) em camundongos. (Masters Theses). Universidade Federal do Ceará, Fortaleza, Brasil.

Haley, P.J., 2012. Small molecule immunomodulatory drugs: challenges and approaches for balancing efficacy with toxicity. Toxicol. Pathol. 40, 261-266. http://dx.doi.org/ $10.1177 / 0192623311427569$.

Harkness, J.E., Turner, P.V., VandeWoude, S., 2010. Harkness and Wagner's Biology and Medicine of Rabbits and Rodents. John Wiley \& Sons, Iowa, USA.

Illnait Ferrer, J., 2007. Principales referencias etnomédicas sobre el Anamú (Petiveria alliacea Linn) y principios activos encontrados en la planta. Un acercamiento al tema. Rev. CENIC Cienc. Biol. 38, 27-30.

Institute for Laboratory Animal Research, 2011. Guide for the Care and Use of Laboratory Animals, eight ed. The National Academy Press, Washington, D.C.

Kerdudo, A., Gonnot, V., Ellong, E.N., Boyer, L., Michel, T., Adenet, S., Rochefort, K., Fernandez, X., 2015. Essential oil composition and biological activities of Petiveria alliacea L. from Martinique. J. Essent. Oil Res. 27, 186-196. http://dx.doi.org/10. $1080 / 10412905.2015 .1014118$.

Kim, S., Kubec, R., Musah, R.A., 2006. Antibacterial and antifungal activity of sulfurcontaining compounds from Petiveria alliacea L. J. Ethnopharmacol. 104, 188-192. http://dx.doi.org/10.1016/j.jep.2005.08.072.

Kubec, R., Kim, S., Musah, R.A., 2002. S-substituted cysteine derivatives and thiosulfinate formation in Petiveria alliacea-part II. Phytochemistry 61, 675-680.

Lemus-Rodríquez, Z., García-Pérez, M.E., Batista-Duharte, A., De la Guardia Peña, O., Alfonso-Castillo, A., 2004. La tableta de Anamú: Un medicamento herbario inmunoestimulante. Medisan 8, 57-64.

Luz, D.A., Pinheiro, A.M., Silva, M.L., Monteiro, M.C., Prediger, R.D., Ferraz Maia, C.S., Fontes-Júnior, E.A., 2016. Ethnobotany, phytochemistry and neuropharmacological effects of Petiveria alliacea L. (Phytolaccaceae): a review. J. Ethnopharmacol. 185, 182-201.

Mariotti, F., Tomé, D., Mirand, P.P., 2008. Converting nitrogen into protein-beyond 6.25 and Jones' factors. Crit. Rev. Food Sci. Nutr. 48, 177-184. http://dx.doi.org/10. 1080/10408390701279749.

Martínez-Pilar, M.-M., Baracaldo-Barrera, N., Santos-Obregón, M., Nieves-Guzmán, D., 2003. Estudio farmacognóstico, fitoquímico y microbiológico de la Petiveria alliaceae Lin. Gac. Méd. Spirit 5.

Michael, B., Yano, B., Sellers, R.S., Perry, R., Morton, D., Roome, N., Johnson, J.K., Schafer, K., 2007. Evaluation of organ weights for rodent and non-rodent toxicity studies: a review of regulatory guidelines and a survey of current practices. Toxicol. Pathol. 35, 742-750. http://dx.doi.org/10.1080/01926230701595292.

Montanher, A.B., Zucolotto, S.M., Schenkel, E.P., Fröde, T.S., 2007. Evidence of antiinflammatory effects of Passiflora edulis in an inflammation model. J. Ethnopharmacol. 109, 281-288.

Navarro, C., 2008. El anamú, la inmunología y el cáncer. Rev. Pesqui. Javer 8. 〈http:// www.javeriana.edu.co/pesquisa/el-anamu-la-inmunologia-y-el-cancer/ $>$ (Accessed 15 January 2017).

Neves, I.I. de A., Camara, C.A.G. da, Oliviera, J.C.S. de, Almeida, A.V. de, 2011. Acaricidal activity and essential oil composition of Petiveria alliacea L. from pernambuco (Northeast Brazil). J. Essent. Oil Res. 23, 23-26. http://dx.doi.org/10. 1080/10412905.2011.9700426.

Núñez, B., Vanegas, D., Torres, G., 1983. Caquexia muscular distrófica y su relación clínico-patológica con neurotoxicidad retardada. Rev. ICA 28, 345-383.

OECD, 1999. Principes de bonnes pratiques de laboratoire et vérification du respect de ces principes. Organisation for Economic Co-operation and Development, Paris.

OECD, 2002. Test No. 423: Acute Oral toxicity - Acute Toxic Class Method. Organisation for Economic Co-operation and Development, Paris.

OECD, 2008. Test No. 407: Repeated Dose 28-day Oral Toxicity Study in Rodents Organisation for Economic Co-operation and Development, Paris.

Oliveira, G.L., Oliveira, A.F.M., Andrade, L., de, H.C., 2015. Medicinal and toxic plants from Muribeca alternative health center (Pernambuco, Brazil): an ethnopharmacology survey [www document]. Bol. Latinoam. Caribe Plantas Med. Aromáticas (WWW Document) 〈http://www.redalyc.org/articulo.oa?id = 85642430005〉 (Accessed 15 January 2017).

Pearson, S., Stern, S., McGavack, T.H., 1953. Rapid, accurate method for determination of total chlolesterol in serum. Anal. Chem. 25, 813-814.

Probst, R.J., Lim, J.M., Bird, D.N., Pole, G.L., Sato, A.K., Claybaugh, J.R., 2006. Gender differences in the blood volume of conscious sprague-dawley rats. J. Am. Assoc. Lab. Anim. Sci. JAALAS 45, 49-52.

Quadros, M.R., Souza Brito, A.R., Queiroz, M.L., 1999. Petiveria alliacea L. extract protects mice against Listeria monocytogenes infection-effects on bone marrow progenito cells. Immunopharmacol. Immunotoxicol. 21, 109-124.

Queiroz, M.L., Quadros, M.R., Santos, L.M., 2000. Cytokine profile and natural killer cell activity in Listeria monocytogenes infected mice treated orally with Petiveria alliacea extract. Immunopharmacol. Immunotoxicol. 22, 501-518.

Reitman, S., Frankel, S., 1957. A colorimetric method for the determination of serum glutamic oxalacetic and glutamic pyruvic transaminases. Am. J. Clin. Pathol. 28, 56-63.

Roig, J., 1974. Plantas medicinales, aromáticas o venenosas de Cuba. Editorial Científico Técnica, La Habana, Cuba.

Rösner, H., Williams, L.A.D., Jung, A., Kraus, W., 2001. Disassembly of microtubules and inhibition of neurite outgrowth, neuroblastoma cell proliferation, and MAP kinase tyrosine dephosphorylation by dibenzyl trisulphide. Biochim. Biophys. Acta BBA Mol. Cell Res. 1540, 166-177. http://dx.doi.org/10.1016/S0167-4889(01)00129-X.

Santander, S.P., Hernández, J.F., Barreto, C.C., Cifuentes, B., C, Masayuki, A., M, A., Moins-Teisserenc, H., H, M.-T., Fiorentino, S., 2012. Immunomodulatory effects of 
aqueous and organic fractions from Petiveria alliacea on human dendritic cells. Am. J. Chin. Med. 40, 833-844.

Sathiyabalan, G., Packia Lincy, M., Muthukumarasamy, S., Mohan, V., 2014. GC-MS analysis of bioactive components of Petiveria alliacea $L$. Whole plant (Phytolaccaceae). Int. J. Pharma Res. Health Sci. 2, 387-392.

Urueña, C., Cifuentes, C., Castañeda, D., Arango, A., Kaur, P., Asea, A., Fiorentino, S., 2008. Petiveria alliacea extracts uses multiple mechanisms to inhibit growth of human and mouse tumoral cells. BMC Complement. Altern. Med. 8, 60.

Villar, R., Calleja, J.M., Morales, C., Cáceres, A., 1997. Screening of 17 Guatemalan medicinal plants for platelet antiaggregant activity. Phytother. Res. 11, 441-445.
http://dx.doi.org/10.1002/(SICI)1099-1573(199709)11:6 < 441::AID-PTR126>3.0. $\mathrm{CO} ; 2-\mathrm{T}$.

Williams, L.A.D., The, T.L., Gardner, M.T., Fletcher, C.K., Naravane, A., Gibbs, N.,

Fleishacker, R., 1997. Immunomodulatory activities of Petiveria alliacea L. Phytother. Res. 11, 251-253.

Zhang, Y., Zhu, K., Cui, H., Liu, Y., Lu, Y.-F., Pan, H.-W., Zhao, H.-P., Qi, L., Yang, X.-D., Zhou, H.-L., 2017. Toxicological evaluation of Oviductus ranae: acute, sub-acute and genotoxicity studies in mice and rats. J. Ethnopharmacol. 203, 101-109. http://dx. doi.org/10.1016/j.jep.2017.03.032. 